\title{
RAVER1 wt Allele
}

National Cancer Institute

\section{Source}

National Cancer Institute. RAVER1 wt Allele. NCI Thesaurus. Code C131186.

Human RAVER1 wild-type allele is located in the vicinity of 19p13.2 and is approximately $17 \mathrm{~kb}$ in length. This allele, which encodes ribonucleoprotein PTB-binding 1 protein, plays a role in the regulation of alternative splicing. 